On Rules 



\title{
On Rules
}

\author{
Gherardo Colombo
}

Translated by Elisabetta Zoni

With an introduction by René Foqué

AUP / Comenius 
First published as Sulle regole in March 2008 by Giangiacomo Feltrinelli

Editore, Milan, Italy

(C) Giangiacomo Feltrinelli Editore, 2008

Translated by: Elisabetta Zoni

This book is published in collaboration with :

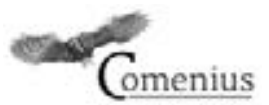

Cover illustration: Giorgio Lotti

Cover design: Rob Wadman

Lay-out: Crius Group, Hulshout

Amsterdam University Press English-language titles are distributed in the US and Canada by the University of Chicago Press.

ISBN $\quad 9789462981942$

e-ISBN $\quad 9789048531745$ (pdf)

e-ISBN 9789048531752 (ePub)

NUR $\quad 740$

(C) Gherardo Colombo / Amsterdam University Press B.V., Amsterdam 2015 Introduction: (C) René Foqué

All rights reserved. Without limiting the rights under copyright reserved above, no part of this book may be reproduced, stored in or introduced into a retrieval system, or transmitted, in any form or by any means (electronic, mechanical, photocopying, recording or otherwise) without the written permission of both the copyright owner and the author of the book.

Every effort has been made to obtain permission to use all copyrighted illustrations reproduced in this book. Nonetheless, whosoever believes to have rights to this material is advised to contact the publisher. 